\title{
Changes in Schooling Arrangements and in the Demographic and Social Profile of Teachers in Iceland, 1930-1960
}

\author{
ÓLÖF GARĐARSDÓTTIR * \\ LOFTUR GUTTORMSSON **
}

\section{Keywords}

Teachers, female teachers, social origin, urbanization, ambulatory schools

\begin{abstract}
This article examines the demographic and social profile of primary school teachers in Iceland over half a century, beginning with the introduction of mandatory elementary school attendance in 1908, with particular focus on changes between 1930 and 1960. During this period, Iceland developed from a rural to a predominantly urban society where most children attended classes in permanent school buildings, in contrast to the ambulatory schools most common at the outset. It is our hypothesis that these rapid social changes affected the composition of the teaching corpus in many ways, particularly as regards gender and class origin. Analysis shows that in the first half of the period, female teachers were more numerous in the capital of Reykjavík, and their social and educational status was higher than teachers outside the capital. Furthermore, female teachers in Reykjavík were less likely to marry and had longer teaching careers than their male colleagues. On the whole, the share of female teachers increased considerably between 1930 and 1960, by which time it had become easier for women to combine teaching with marriage.
\end{abstract}

To cite this article

Ólöf Garðarsdóttir and Loftur Guttormsson, "Changes in Schooling Arrangements and in the Demographic and Social Profile of Teachers in Iceland, 1930-1960," Nordic Journal of Educational History 1, no. 1 (2014), 7-20.

\section{Introduction}

In the first half of the twentieth century, Iceland underwent significant social and economic changes. At the beginning of the century, the vast majority of its population lived in sparsely populated rural regions, but by the 1960s this was true for less than one-quarter of the population. One manifestation of this change was an important transformation in compulsory schooling and the demographic and social profile of teachers.

The present article is part of an ongoing research project on teachers in Iceland, from the date when the formal education of teachers was first introduced at the beginning of the twentieth century until teachers' education was upgraded to university level in the early 1970 . Here we compare the social and demographic profile of

\footnotetext{
* Professor of History, School of Education, University of Iceland. Email: olofgard@hi.is.

${ }^{* * *}$ Professor Emeritus of History, School of Education, University of Iceland. Email: loftur@hi.is.
} 
teachers, including all individuals teaching in Icelandic compulsory schools in 1930 and in 1960, respectively. The study compares urban and rural areas as well as different school types. How did urbanization affect teachers in different settings? Did urbanization lead to a differentiation between teachers in urban and rural areas in terms of their professional preparation and social status? We will furthermore focus on the feminization of the teaching profession. Was there a difference between the views of female and male teachers toward their profession and family life? To what extent did the growth in wage labor among married women in the 1950 s affect those views? In this article we only marginally address the issue of the educational status of teachers, since that issue will be dealt with in a forthcoming article. Our main source material is a dataset containing a cross-section of information on all individuals teaching in primary schools and lower secondary schools in the years 1909-10, 1930-31, 1940-41 and $1960-61 .^{i}$ The dataset is unique in the sense that it contains detailed information on the social background and teaching careers of all individuals teaching at the compulsory school level in Iceland at the time (for a further description of the dataset, see below).

\section{Characteristics of Schooling Arrangements in Iceland, 1900-1960}

Compared to the other Nordic countries, free public schooling became compulsory at a late date in Iceland. Iceland had a deep-rooted tradition of home instruction, and compulsory schooling was not introduced until $1907 .{ }^{1}$ This was mainly due to the fact that the country was sparsely populated, even by North European standards. Settlement was scattered along the coast and inland valleys and the vast interior was largely uninhabited. Although the majority of the population lived off animal husbandry, fisheries constituted an important subsidiary source of livelihood for a relatively large proportion of the population, in particular in the western and southern parts of the country. In upland rural areas, settlement was characterized by isolated farmsteads, whereas many of the coastal areas were more densely populated. The total population by 1901 was slightly over 80,00o. Reykjavík, which eventually became the capital of Iceland, was by far the most populated town, with 6,600 inhabitants. Outside Reykjavík there were a handful of towns and villages with a population of more than two hundred. It goes without saying that the operation of regular schools in permanent housing would have been complicated under such conditions. ${ }^{2}$

It is important to note that the Compulsory Education Act of 1907 did not entail any clear shift in either the organization of schools or in school attendance. A burgeoning interest in promoting the establishment of primary school occurred in second part of the nineteenth century, and in 1880 a new Education Act was passed by parliament. Until then, the traditional requirement for receiving first communion (alongside knowledge of the catechism) was that children should be able to read texts freely and not only learn them by heart. With the Education Act of 1880 , new requirements were added: individual households were now made responsible for teaching children to

\footnotetext{
${ }^{1}$ Loftur Guttormssson, "Tímamótin 1907," in Almenningsfræðsla á Íslandi 1880-2007: Skólahald í bæ og sveit 1880-1945, ed. Loftur Guttormsson (Reykjavík: Háskólaútgáfan, 2008a), 75-89.

2 On poplation development in Iceland, see Hagskinna: Icelandic Historical Statistics, ed. Guðmundur Jónsson and Magnús S. Magnússon (Reykjavík: Statistics Iceland, 1997), 85.
} 
write and master some basic arithmetic skills. ${ }^{3}$ It has been argued that households were often unequipped to meet the new educational demands, which brought about a shift in educational arrangements in both urban and the rural settings. Thus, in the following years there was a sharp increase in the number of schools, both in villages and rural areas. By the turn of the twentieth century, there were ambulatory (or itinerant) schools in the majority of rural districts and permanent schools were established in almost every village. 4 Generally, ambulatory schools were operated on a temporary basis at a number of farms in the local community. During the year, the teacher travelled between the farms where the "school" was operated. Consequently, the school year for individual children only lasted for a period of around two months.

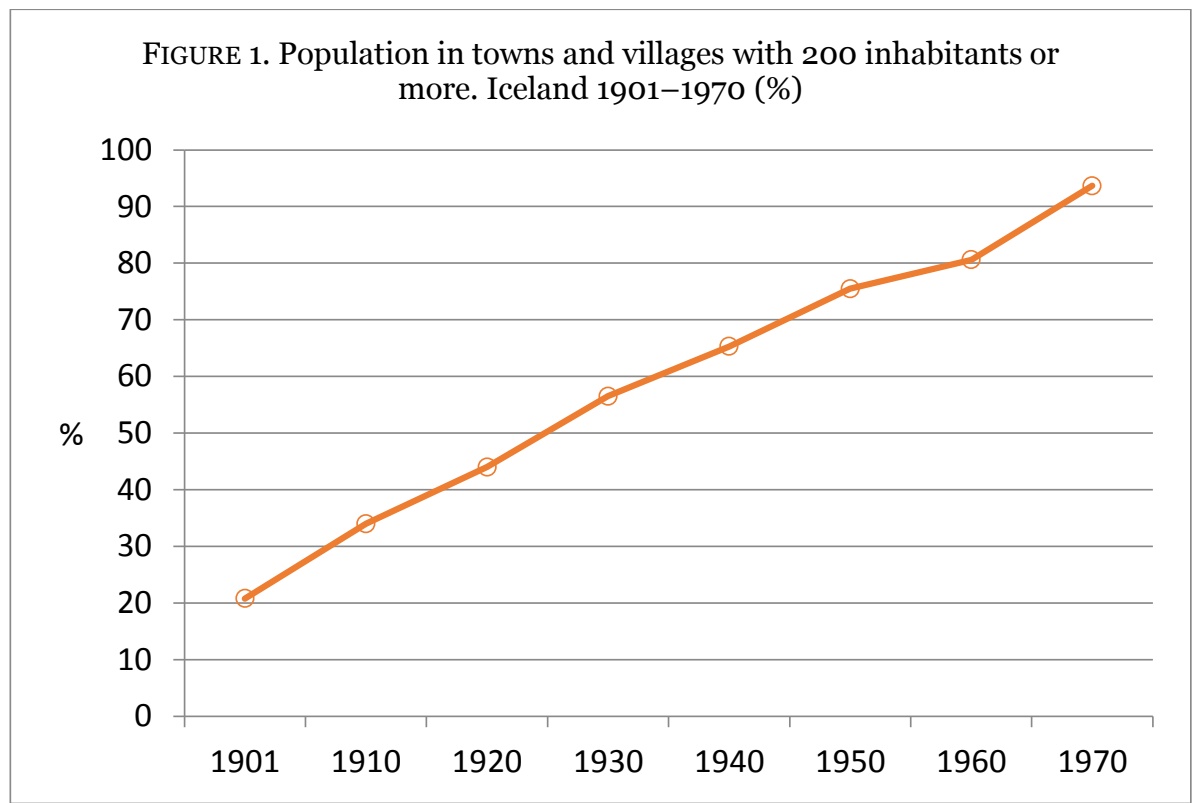

Source: Jónsson and Magnússon (1997), 85.

The early twentieth century was characterized by rapid population growth and a shift in settlement pattern. Fisheries increased in economic importance and consequently the rural population declined while coastal towns and villages expanded. In 1901, only $20 \%$ of the population lived in towns and villages with 200 inhabitants or more. However, by 1930 this was true for more than half of the population and by 1960 for 80\% (Figure 1). This radical shift had an important bearing upon the organization of schools in Iceland. With a denser settlement pattern, preconditions were created for establishing schools on a more permanent basis. It is, however, evident that traditional patterns prevailed and there was a clear distinction between schooling in urban and rural areas until the post-war period.

\footnotetext{
3 Loftur Guttormsson, "Sekuleringstendenser i islandsk almuedannelse i slutningen af 180o-tallet," in Skole, dannelse, samfund: Festskrift til Vagn Skovgaard-Petersen, ed. Harry Haue (Odense: Odense Universitetsforlag, 1991), 87-95.

${ }^{4}$ Loftur Guttormsson, ”Hefð og nýbreytni mætast," in Almenningsfræðsla á Íslandi 188o-20o7: Skólahald í bæog sveit 1880-1945, ed. Loftur Guttormsson (Reykjavík: Háskólaútgáfan, 2008b), 47-48.
} 


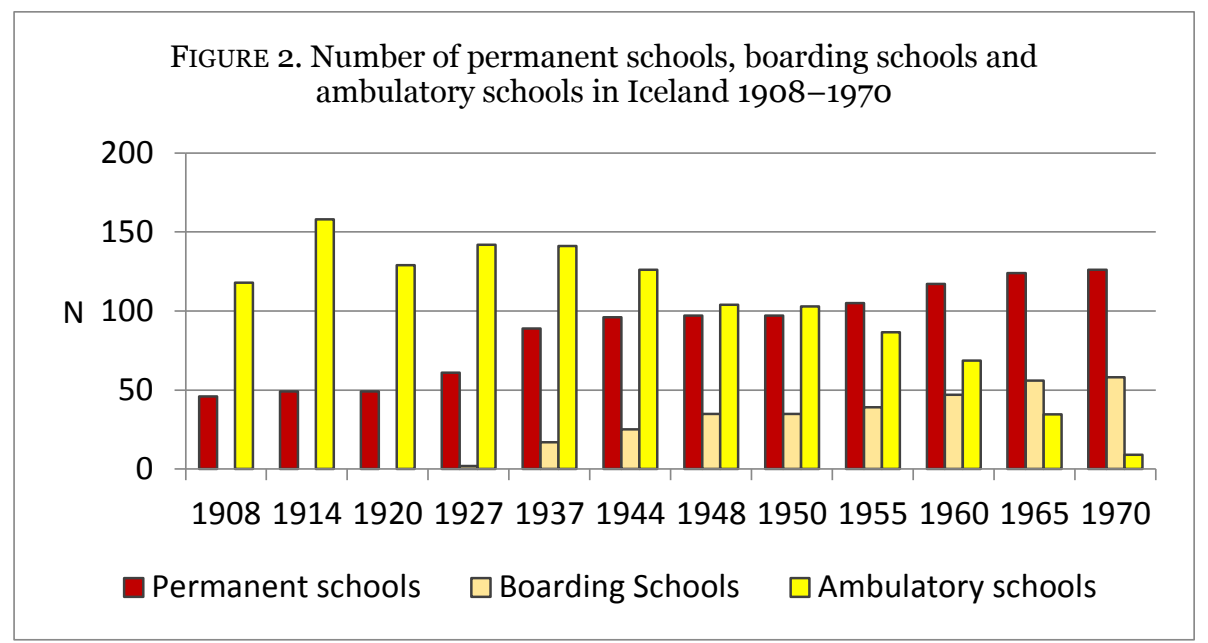

Source: Barnafræðsluskýrslur árin 1920-1966 (Reykjavík: Hagstofa Íslands, 1967).

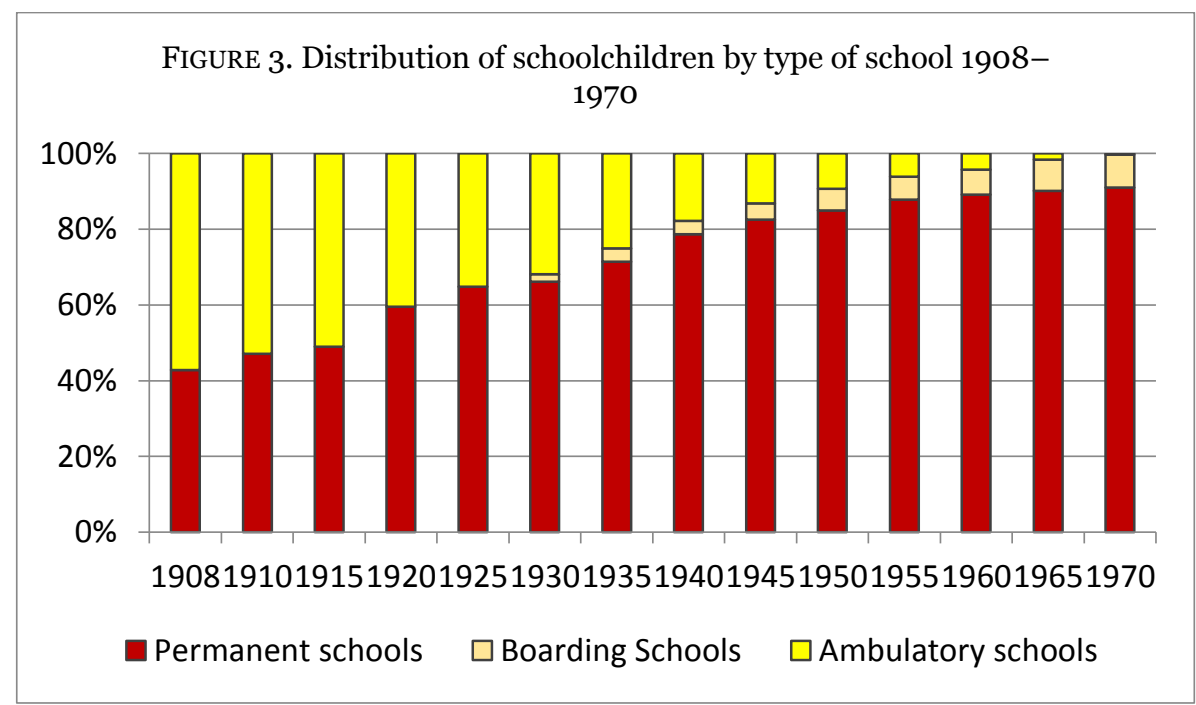

Source: Barnafræðsluskýrslur árin 1920-1966 (1967).

The other Nordic countries strove to centralize the school system in the early twentieth century, and an increased attempt was made to organize schools uniformly, irrespective of geographic and economic setting. ${ }^{5}$ In Iceland, on the other hand, prevailing

5 Edmund Edvardsen, Den gjenstridige allmue: Skole og levebrød i et nordnorsk kystsamfunn c. 1850-190o (Oslo: Solum forlag, 1989); Ning de Conick-Smith, "The Struggle for the Child's Time - at All Times: School and Children's Work in Town and Country in Denmark from 1900 to the 196os," in Industrious Children: Work and Childhood in the Nordic Countries 1850-1990, ed. Ning de Conick-Smith, Bengt Sandin and Ellen Schrumpf (Odense: Odense University Press, 1997), 150; Gunhild Nissen, Bønder, skole og demokrati: En undersøgelse i fire provstier af forholdet mellem den offentlige skole og befolkningen på landet it tiden ca. 1880-1910 (Copenhagen: Institut for Dansk Skolehistorie, 1973), 335-45; Mats Sjöberg, Att säkra familjens skördar: Barndom, skola och arbete $i$ agrar miljö: Bolstad pastorat 1860-1930 (Linköping: Linköping Universitet, 1996), 123-4. 
structures were consolidated and ambulatory schools continued to be the dominant school type in rural areas. This is evident from Figures 2 and 3, which show the number of different school types and the share of children by school type. It is worth mentioning that boarding schools did not become common in rural Iceland until the 1940s and ' 50 , in sharp contrast with e.g. Norway where many children in the northernmost region of Finnmark attended boarding schools early in the twentieth century. ${ }^{6}$ With the founding of boarding schools in Iceland, the number of ambulatory schools declined. It was not, however, until the late 1960 s that ambulatory schools disappeared entirely.

In the Icelandic case, there were vast differences between ambulatory and permanent schools. First and foremost, the school year was considerably shorter in ambulatory schools. A school year of between eight and twelve weeks continued to be the general rule in ambulatory schools as late as the 1950s, compared to six to eight months in the permanent schools in towns and villages.7 Similarly, the school year at boarding schools was rarely longer than three months.

Another important distinction between town and countryside was school age. According to the Education Act of 1907, the compulsory school age was ten-thirteen years, with householders still responsible for teaching children to read before they started school at the age of ten. It was not until 1936 that compulsory schooling for all children from the age of seven was introduced. Earlier, however, it was common that individual towns organized schools for seven- or eight-year-old children. In the case of Reykjavík, a large proportion of children under ten already attended school at the outset of the twentieth century. As regards the rural areas, there was no radical shift in respect to the Education Act of 1936, as it allowed individual school districts to apply for exemption from the principle of school start at age seven. Thus signficant differences did indeed exist. Consequently, the demographic and social profile of primary school teachers in different areas must have also varied considerably.

\section{Icelandic Teachers in 1930 and 1960: Demographic and Social Profile}

Previous research has shown that at the beginning of the twentieth century, there were notable differences in the demographic and social profiles of teachers working in towns and rural areas, respectively. Teaching was often a secondary occupation in Iceland. ${ }^{8}$ The traditional economy was characterized by seasonal variation. In the agrarian sector, the most labor-intensive period lasted from the beginning of May, during lambing, until late September, when the sheep were gathered from the highlands. For individuals who were considered qualified, the option to teach would often have been an attractive alternative during winter, when there was little labor demand in the

\footnotetext{
6 Knut Einar Eriksen and Einar Niemi, Den finske fare: Sikkerhetsproblemer og minoritetspolitikk $i$ nord 1860-1940 (Oslo: Universitetsforlaget, 1981); Henry Minde, "Assimilation of the Sami: Implementation and Consequences," Acta Borealia 2 (2003), 121-46; Eivind Bråstad Jensen, "Skolverket og de tre stammer møte," Eureka 7 (2005).

7 Loftur Guttormsson, ”Farskólahald í sextíu ár (1890-1950): Nokkrir megindrættir,” Uppeldi og menntun 1 (1992), 207-222; Barnafræðsluskýrlsur 1920-1966 (1967).

8 Ólöf Garðarsdóttir, "Teaching on the Eve of Public Schooling. Demographic and Social Features of Icelandic Schoolteachers in the Beginning of the 2oth Century," in Education, State and Citizenship, ed. Mette Buchardt, Pirjo Markkola and Heli Valtonen (Jyväskylä: NordWel Studies in Historical Welfare State Research, 2012), $138-59$.
} 
farming sector. Consequently, a large fraction of teachers were either farmers or the children of farmers.

The profile of teachers in town differed considerably from their rural counterparts. In towns, children most often attended school for at least six months a year and therefore for many teachers, teaching constituted their only, or at least, principal occupation. Furthermore, there were considerable differences in the social and demographic profile of teachers in Reykjavík as compared to teachers outside the capital. For example, in Reykjavík female teachers were more numerous than male teachers and their educational status was higher than teachers outside the capital. ${ }^{9}$

In the following, we will compare the social and demographic profile of teachers in different school types. How did socio-economic changes affect the social and demographic profile of Icelandic compulsory school teachers? And what were the differences between different geographic settings and different school types? Our analysis includes all individuals teaching in Icelandic compulsory schools in 1930 and in 1960. We divide teachers into three distinct categories: (1) Teachers in Reykjavík; (2) Teachers in permanent schools outside Reykjavík (boarding schools included); and (3) Teachers in ambulatory schools.ii

Our main source material is a database containing cross-sectional information on all individuals teaching in primary schools in the years 1909-10, 1930-31, 1940-41 and 1960-61. The information was obtained from the Archive of the Ministry of Education..$^{10}$ The lists from the Ministry contain only basic information, including the name of the individual, the name of the school and the school district. We have subsequently acquired additional information on the individuals from a variety of sources, mainly the "Teachers' Biographies" (Kennaratal á Íslandi) published in 1958 and in $1985 .{ }^{11}$ The majority of individuals figuring in the lists from the Ministry were identified in the biographies: $94 \%$ in 1930 and 90\% in 1960. Additional information collected from the biographies concerns age; marital status (year of marriage, year of divorce and year widowed); number of children (year of birth of the youngest and oldest child); social background (occupation of father and mother when available); education; teaching career (start and end year); and the name of the schools in towns, or of the school district in rural areas.

Table 1 lists the number of teachers in our database by gender in different school types. The last three columns show the proportion that was found in the Teachers' Biographies. Both in 1930 and in 1960 there were gender-specific and "school typespecific" differences in the proportion of teachers listed. Teachers in Reykjavík were more likely to appear in the biographies (in 1930 all 100 teachers figured there). In 1960 the share in Reykjavík is lower than it had been, but remained higher than in the other areas. It is noteworthy that in Reykjavík, women were more likely to appear in the biographies than men, in contrast to areas outside Reykjavík where the opposite was more common. As regards the areas outside Reykjavík, teachers in permanent schools were more likely to figure in the biographies in 1930 than in 1960.

\footnotetext{
9 Ibidem.

10 The database was created by Loftur Guttormsson and Helgi Skúli Kjartansson in the early 2000 . Guttormsson and Ólöf Garðarsdóttir have continued to develop it since.

11 Ólafur P. Kristjánsson, ed., Kennaratal á Íslandi I-II (Reykjavík: Oddi, 1958); Ólafur P. Kristjánsson and Sigrún Harðardóttir, eds. Kennaratal á Íslandi III-V (Reykjavík: Oddi, 1985-1988).
} 


\begin{tabular}{|l|c|c|c|c|c|c|}
\hline \multicolumn{5}{|c|}{$\begin{array}{l}\text { TABLE 1. Number of Icelandic teachers 1930 and 1960. } \\
\text { Percentage figuring in Teachers' Biographies (TB) by school type }\end{array}$} \\
\hline $\mathbf{1 9 3 0}$ & $\begin{array}{c}\text { Number } \\
\text { Both }\end{array}$ & Men & Women & Both & Men & Women \\
\hline Total & $\mathbf{4 1 8}$ & $\mathbf{2 9 7}$ & $\mathbf{1 2 1}$ & $\mathbf{9 4 . 0}$ & $\mathbf{9 4 . 9}$ & $\mathbf{9 1 . 7}$ \\
\hline Teachers in Reykjavík & 100 & 56 & 44 & 100.0 & 100.0 & 100.0 \\
\hline Permanent schools outside Reykjavík & 194 & 143 & 51 & 93.8 & 96.5 & 86.3 \\
\hline Ambulatory school teachers & 124 & 98 & 26 & 89.5 & 89.8 & 88.5 \\
\hline $\mathbf{1 9 6 0}$ & & & & & & \\
\hline Total & $\mathbf{1 4 0 0}$ & $\mathbf{9 2 7}$ & $\mathbf{4 7 3}$ & $\mathbf{9 0 . 0}$ & $\mathbf{9 1 . 7}$ & $\mathbf{8 6 . 7}$ \\
\hline Teachers in Reykjavík & 503 & 305 & 198 & 95.0 & 93.4 & 97.5 \\
\hline Permanent schools outside Reykjavík & 831 & 576 & 255 & 87.0 & 90.8 & 78.4 \\
\hline Ambulatory school teachers & 66 & 46 & 20 & 89.4 & 91.3 & 85.0 \\
\hline
\end{tabular}

Source: Icelandic school teachers. Database.

Judging from the more complete accounting of teachers in Reykjavík and at permanent schools, the gender- and school-specific differences detailed in the biographies certainly in 1930 - are a clear indication of a disparity in status between areas. In all likelihood, the editors of these biographies were more prone to publish information on individuals for whom teaching was their sole profession than teachers for whom teaching was an ancillary occupation. Individuals who had been trained as teachers or possessed other professional merits were also more likely to report to the editors.

Let us now have a closer look at the demographic and social features of Icelandic teachers. Figure 4 shows the distribution of teachers in different school types. For comparative purposes, this analysis includes individuals teaching in 1909 together with teachers active in 1930 and 1960. In 1909, a majority of teachers (56\%) worked in ambulatory schools; by 1930, their share had declined to a third, and by 1960 only a negligible proportion of all teachers worked in ambulatory schools. Only a tiny fraction of teachers taught in boarding schools, despite the fact that their share increased notably between 1930 and 1960. The share of teachers in permanent schools increased, particularly in Reykjavík (from $11 \%$ in 1909 to $36 \%$ in 1960).

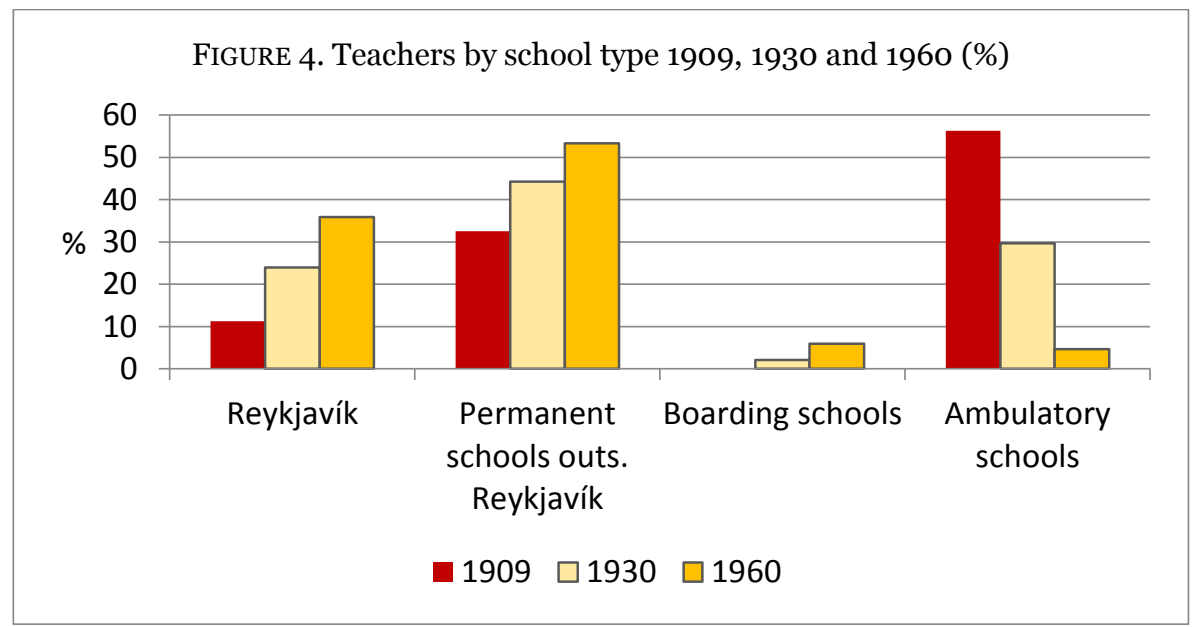

Source: See Table 1. 
TABLE 2. Teachers by gender in different school types 1930 and 1960

\begin{tabular}{|l|c|c|c|c|}
\hline & \multicolumn{3}{|c|}{ Number of teachers } & \multirow{2}{*}{ Women } \\
\hline T930 & Total & Men & Women & \multirow{2}{*}{ Per cent } \\
\hline Tetal & $\mathbf{4 1 8}$ & $\mathbf{2 9 7}$ & $\mathbf{1 2 1}$ & $\mathbf{2 8 . 9}$ \\
\hline In permanent schools outside Reykjavik & 100 & 56 & 44 & 44.0 \\
\hline Teachers in ambulatory schools & 194 & 143 & 51 & 26.3 \\
\hline $\mathbf{1 9 6 0}$ & 124 & 98 & 26 & 21.0 \\
\hline Total & & & & \\
\hline Teachers in Reykjavík & $\mathbf{1 , 4 0 0}$ & $\mathbf{9 2 7}$ & $\mathbf{4 7 3}$ & $\mathbf{3 3 . 8}$ \\
\hline In permanent schools outside Reykjavik & 503 & 305 & 198 & 39.4 \\
\hline Teachers in ambulatory schools & 831 & 576 & 255 & 30.7 \\
\hline
\end{tabular}

Source: See Table 1.

Table 2 shows that not only did the proportion of ambulatory teachers decline between 1930 and 1960, the decline was also noteworthy in absolute numbers (from 124 to 66). As regards teachers in Reykjavik, the increase was more than fivefold, and in the permanent schools outside Reykjavík, the number of teachers in 1960 was four times that of 1930. As in earlier periods, female teachers were more numerous in Reykjavík than in other areas. This result is consistent with earlier research on the situation in the very early twentieth century; female teachers in Reykjavík were slightly more numerous than men in both 1901 and in 1909. ${ }^{12}$ A comparison with Norway shows that female teachers were far more numerous in large Norwegian towns than was the case in rural areas. ${ }^{13}$

It has been argued that the professionalization of teaching in Iceland largely occurred prior to 1930. ${ }^{14}$ The founding of the Teachers' Training College in Reykjavík in 1908 marked an important shift in this respect; during the following decades, between twenty and thirty individuals graduated every year. The change in the teachers' profiles is reflected in changes in their ages. Earlier research has shown that at the beginning of the century, the majority was young and unmarried and had often been involved in teaching for only a brief period of time. ${ }^{15}$ In 1930, teachers were on the average older and had longer teaching careers than their forerunners. Thus, $70 \%$ of all teachers in the permanent schools (both in and beyond Reykjavík) were thirty years or older (compare Figures $5 \mathrm{~A}$ and C). This was, however, not the case with the ambulatory teachers who displayed similar demographic characteristics as in earlier periods when it was not uncommon for individuals in the countryside to teach only for a brief period of time before they married and went on to pursue new careers. Often farmers' children chose to teach for a few years before they married and established a household. A large fraction of these teachers taught only for a shorter period. ${ }^{16}$ Our study indicates that these structures prevailed in 1930 (see Figure $5 \mathrm{E}$ ). Table 3 shows

\footnotetext{
12 Garðarsdóttir (2012); Loftur Guttormsson, “Barnakennarar: Starfskjör, menntun og staða,” in Almenningsfræðsla á Íslandi 1880-2007: Skólahald í bæ og sveit, 1880-1945, ed. Loftur Guttormsson (Reykjavík: Háskólaútgáfan, 2008c), 126-41.

13 Gro Hagemann, Skolefolk: Lærernes historie i Norge (Oslo: Gyldendal, 1992), 70-71.

14 On the professionalization of teachers in the early 2oth century see Guttormsson (2008c); Garðarsdóttir (2012).

15 Garðarsdóttir (2012).

16 Garðarsdóttir (2012).
} 
that the teaching careers of ambulatory school teachers were on average much shorter than permanent school teachers. This was especially true for women - two out of three female ambulatory teachers taught for less than five years in 1930, a situation which had changed by 1960 .

FIGURES 5. A-F. Number of teachers in different types of schools by age group, gender and marital status, 1930 and 1960
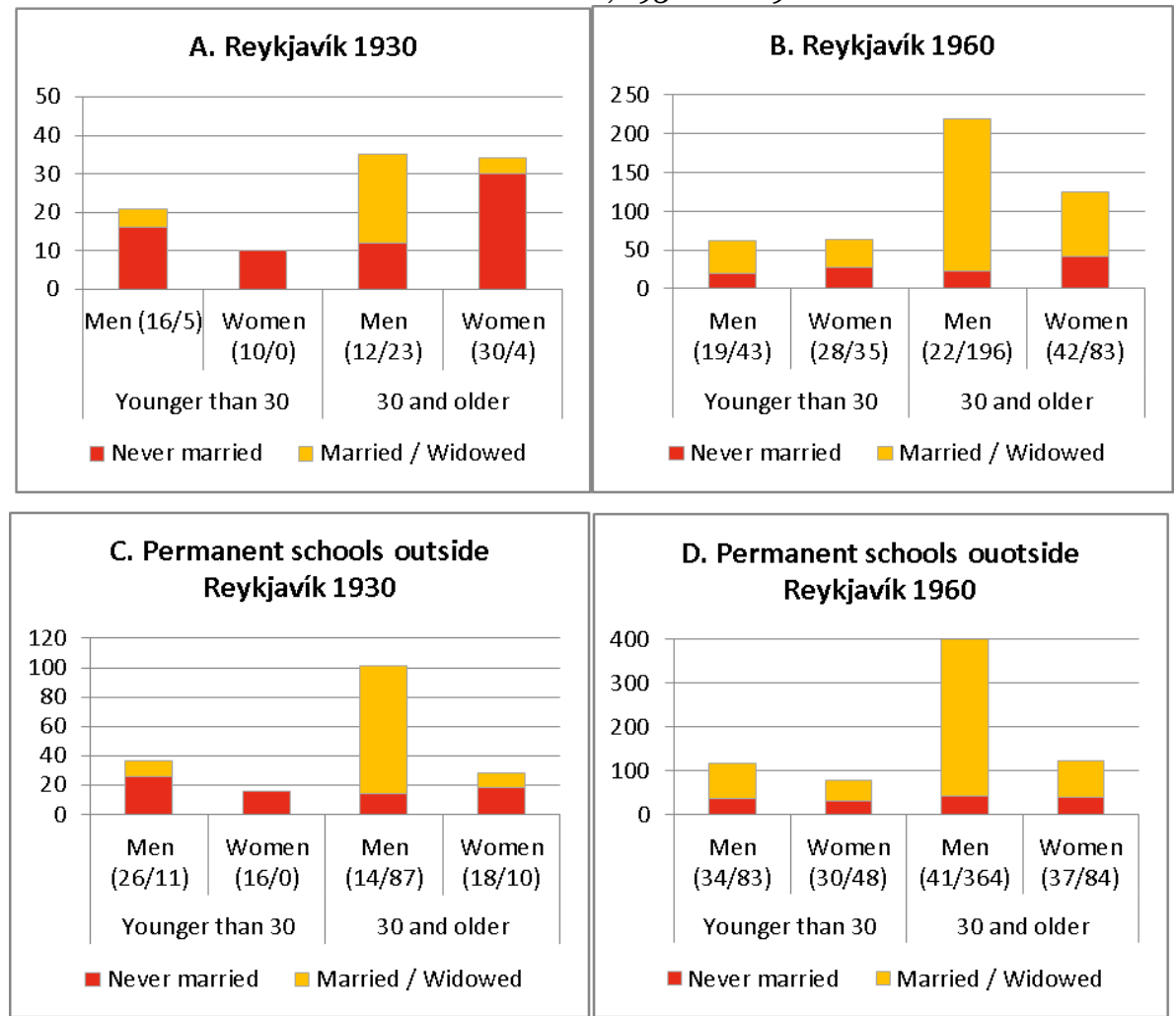

\section{Permanent schools ouotside Reykjavík 1960}

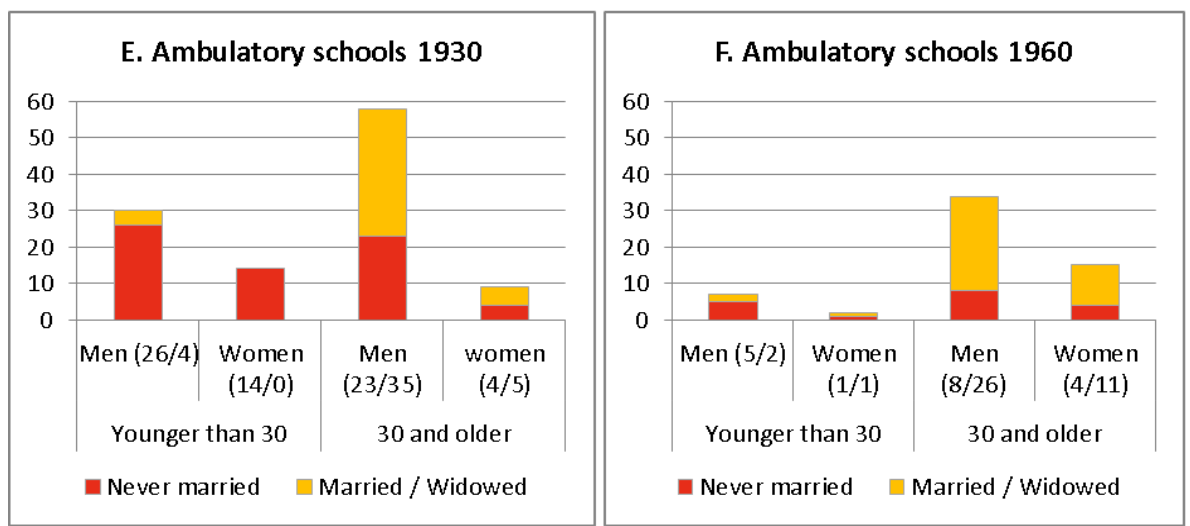

Source: See Table 1. 
With escalating urbanization between 1930 and 1960, there was a considerable decline in the number of ambulatory teachers and thus little renewal in this group. Only a minority were under thirty years of age in 1960 (seven out of 41 men and two of 17 women) (Figure 5. F). An analysis of the length of teaching careers shows that more than one-third (35\%) of ambulatory teachers had been teaching for twenty-five years or more (Table 3). The same holds true for fewer than $20 \%$ of teachers in permanent schools.

\begin{tabular}{|l|l|l|l|l|l|l|l|l|l|l|}
\hline \multicolumn{7}{|l|}{ TABLE 3. Length of teaching carreer. Icelandic teachers 1930 and 1960 by type of } \\
School and gender \\
\hline
\end{tabular}

Source: See Table 1.

Our study shows that female teachers were relatively few in 1930, and only a small fraction of them were married or widowed (Figure $5 \mathrm{~A}, \mathrm{C}$ and $\mathrm{E}$ ). At that time, the domestic ideal emphasizing separate spheres prevented married women from pursuing a professional career. Here, however, interesting differences between school types emerge. In Reykjavík, female teachers seem to have been more likely to adhere to the ideal, as only four out of 44 female teachers in Reykjavík were married in 1930 (Figure 5 A). Furthermore, they had longer teaching careers than their male counterparts in the capital and both male and female teachers outside Reykjavik. More than half of them had been teaching for more than fifteen years (see table 3). On the other hand, female teachers outside Reykjavík were more likely to be married or widowed than their colleagues in Reykjavík; there, fifteen out of 37 women above the age of thirty were married. Below, we will discuss the impact of the domestic ideal in relation to the social background of teachers.

Even though there were still considerable gender-specific differences in the marital status of teachers in 1960, the share of married female teachers had increased considerably between 1930 and 1960. By 1960, it had evidently become easier for women to combine teaching with marriage and childrearing. Similar results have been recorded for other female professions at the time. In the case of nurses, the $1950 \mathrm{O}$ marked a clear shift, as it became common for nurse candidates to be married and 
often pregnant when they embarked on their professional preparation. ${ }^{17}$ This shift must be seen in the light of changing demographic patterns, since the 1950s were marked by a notable decline in the age at marriage, together with an increase in the proportion of married people. The period was also characterized by changes in normative views on women's role in society.

In most European societies, women played a crucial role in the development of public schools beginning in the late nineteenth century. ${ }^{18}$ Furthermore, it has been shown that female teachers often had a higher social profile than their male counterparts. Domestic studies indicate that this also holds true for Iceland, in particular for Reykjavík. Female teachers were more numerous than male teachers and their educational status was higher than female teachers outside the capital. ${ }^{19}$ Our study shows that these structures prevailed in 1930. Thus, the social profile of female teachers in Reykjavík was very different from other teachers.

It is hardly surprising that in 1930, the majority of Icelandic teachers were the children of farmers. This was true for three out of four teachers outside Reykjavík as well as for male teachers in Reykjavík (Table 4). As for female teachers in Reykjavík, the share was much lower (below 40\%). A large fraction of the female teachers in Reykjavík originated from the upper middle class and no less than one out of four had fathers who were academic professionals. Women originating from this social class were likely more prone than others to be influenced by the domestic ideal, in the sense of having to choose between marriage and a professional career. ${ }^{20}$

TABLE 4. Teachers' social background (occupation of fathers) in Reykjavík vs. outside Reykjavík 1930 and 1960 (percentage)

\begin{tabular}{|l|c|c|c|c|c|}
\hline \multirow{2}{*}{1930} & \multicolumn{2}{|c|}{ Reykjavík } & \multicolumn{2}{c|}{ Outside Reykjavík } \\
\hline Tradesmen (incl. fishermen) & Men & Women & Men & Women \\
\hline Farmers & 5.4 & 6.8 & 7.1 & 3.0 \\
\hline Skilled labor, artisans & 75.0 & 38.6 & 77.9 & 73.1 \\
\hline Technical, teachers & 7.1 & 4.5 & 3.5 & 6.0 \\
\hline Entrepreneurs & 7.1 & 15.9 & 3.1 & 4.5 \\
\hline Academic professionals & 1.8 & 6.8 & 4.4 & 6.0 \\
\hline Not known & 3.6 & 25.0 & 3.1 & 6.0 \\
\hline 196o & 0.0 & 2.3 & 0.9 & 1.5 \\
\hline & & & 0 Outside Reykjavík \\
\hline Tradesmen (incl. fishermen) & Men & Women & Men & Women \\
\hline Farmers & 14.2 & 5.7 & 13.0 & 8.3 \\
\hline Skilled labor, artisans & 43.6 & 37.8 & 54.8 & 46.5 \\
\hline Technical, teachers & 14.5 & 16.6 & 9.9 & 17.5 \\
\hline Entrepreneurs & 15.2 & 20.2 & 11.3 & 17.1 \\
\hline Academic professionals & 9.6 & 11.4 & 7.6 & 8.8 \\
\hline Not known & 2.8 & 6.7 & 3.0 & 1.4 \\
\hline
\end{tabular}

Source: See Table 1.

17 Margrét Guðmundsdóttir, Saga hjúkrunar á Íslandi á 20. öld (Reykjavík: Félag íslenskra hjúkrunarfræðinga, 2010), 316-20.

18 See for example Christina Florin, Kampen om katedern: Feminiserings- och professionaliseringsprocessen inom den svenska folkskolan (Umeå: Umeå University, 1987); Hageman (1992), 70-71; Dina M. Copelman, London's Women Teachers: Gender, class and feminism 1870-1930 (London: Routledge, 1996), 26-44.

19 Garðarsdóttir (2012). Similar results have been revealed by Florin (1987) for Sweden.

20 See for example Copelman (1996), 194-5, 219-26. 
In this article we have not analyzed the educational status of teachers systematically; however, a brief examination of the teachers' biographies indicates that female teachers in Reykjavík often had sounder professional training than their male counterparts. This is hardly surprising considering the results from studies of the early twentieth century. When analyzing the unique position of female teachers in Reykjavík early in the century, it must be borne in mind that the foundation of the Teachers' Training College laid the ground for the enhancement of job opportunities for women. In most countries, teaching was the prime occupation open both to men and women and initially, women teachers were often well educated and came from the upper strata of society. ${ }^{21}$ Teaching was a way for many women to obtain a sound education and to gain an independent career. As more educational opportunities opened up to women, the class profile of female teachers was bound to change. This is clearly evident in figures on the social background of teachers in 1960 (Table 4). By that time there were only minor gender- and school-type differences in the social background of teachers.

\section{Conclusions}

In the present essay, we have explored how socio-economic changes affected the social and demographic profile of Icelandic primary school teachers during the period 1930 to 1960 . The study compares urban and rural areas as well as different school types. We show that there were considerable differences in the social profile of teachers between settings. In 1930 almost one-third of all Icelandic primary school teachers were ambulatory teachers in rural areas as compared to less than $5 \%$ in 1960 . The share of teachers in permanent schools increased, in particular in Reykjavík. We argue that the professionalization of teaching had already occurred in the first decades of the twentieth century. This is reflected in the change in the age profile of teachers. Earlier research has shown that the majority of teachers in the early $20^{\text {th }}$ century were young and unmarried and often involved in teaching for only a brief period. In 1930, teachers were generally older and had longer teaching careers than their predecessors. This was, however, not the case with the ambulatory teachers, who displayed the same demographic characteristics as their forerunners. With increased urbanization between 1930 and 1960, there was a considerable decline in the number of ambulatory school teachers and, consequently, little renewal within the group. In 1960, teachers in permanent schools were on average younger, as the number of teachers increased more than fourfold between 1930 and 1960. Our study shows that, with the exception of Reykjavík, female teachers were relatively few in 1930, and only a small fraction of female teachers were married, (probably) due to the domestic ideal of the time, inhibiting married women from pursuing careers.

We argue that at the beginning of the twentieth century, there were considerable differences in the social and demographic profile of teachers in Reykjavík as compared to teachers outside the capital. In Reykjavik, female teachers were more numerous than male teachers, and their social and educational status was higher than of teachers outside the capital. Female teachers in Reykjavík were also less likely to be married and had longer teaching careers than their male colleagues.

Even though there were still considerable gender-specific differences in the marital status of teachers in 1960, the share of married female teachers increased considerably

21 Copelman (1996); Gro Hagemann, De modern gennombrudd 1870-1905, Aschehougs Norgeshistorie IX, ed. Knut Helle (Oslo: H. Aschenhoug, 1997), 32. 
between 1930 and 1960, by which time it had evidently become easier for women to combine teaching with marriage and childrearing.

\section{References}

Barnafræðsluskýrslur 1920-1966. Reykjavík: Hagstofa Íslands, 1967.

de Coninck-Smith, Ning. "The Struggle for the Child's Time - at All Times: School and Children's Work in Town and Country in Denmark from 1900 to the 1960s." In Industrious Children: Work and Childhood in the Nordic Countries 1850-1990, edited by Ning de Conick-Smith, Bengt Sandin and Ellen Schrumpf. Odense: Odense University Press, 1997.

Copelman, Dina M. London's Women Teachers. Gender, Class and Feminism 18701930. London: Routledge, 1996.

Edvardsen, Edmund. Den gjenstridige allmue: Skole og levebrød $i$ et nordnorsk kystsamfunn c. 1850-1900. Oslo: Solum forlag, 1989.

Eriksen, Knut Einar and Einar Niemi. Den finske fare. Sikkerhetsproblemer og minoritetspolitikk i nord 186o-1940. Oslo: Universitetsforlaget, 1981.

Florin, Christina. Kampen om katedern: feminiserings- och professionaliseringsprocessen inom den svenska folkskolan. Umeå: Umeå University, 1987.

Garðarsdóttir, Ólöf. "Teaching on the Eve of Public Schooling. Demographic and Social Features of Icelandic Schoolteachers in the Beginning of the 2oth Century." In Education, State and Citizenship, edited by Mette Buchardt, Pirjo Markkola and Heli Valtonen. Jyväskyle: NordWel Studies in Historical Welfare State Research, 2012.

Guðmundsdóttir, Margrét. Saga hjúkrunar á Í slandi á 20. öld. Reykjavík: Félag íslenskra hjúkrunarfræðinga, 2010.

Guttormsson, Loftur. "Sekuleringstendenser i islandsk almuedannelse i slutningen af 180o-tallet." In Skole, dannelse, samfund: Festskrift til Vagn Skovgaard-Petersen, edited by Harry Haue. Odense: Odense Universitetsforlag, 1991.

Guttormsson, Loftur. "Farskólahald í sextíu ár (1890-1950): Nokkrir megindrættir." Uppeldi og menntun 1 (1992).

Guttormsson, Loftur. "Tímamótin 1907." In Almenningsfræðsla á Íslandi 1880-2007: Skólahald i bæ og sveit 1880-1945, edited by Loftur Guttormsson. Reykjavík: Háskólaútgáfan, 2008a.

Guttormsson, Loftur. ”Hefð og nýbreytni mætast.” In Almenningsfræðsla á Íslandi 1880-2007: Skólahald í bæ og sveit, 1880-1945, edited by Loftur Guttormsson. Reykjavík: Háskólaútgáfan, 2008b.

Guttormsson, Loftur. "Barnakennarar: Starfskjör, menntun og staða.” In Almenningsfræðsla á Íslandi 1880-2007: Skólahald í bæo og sveit, 1880-1945, edited by Loftur Guttormsson. Reykjavík: Háskólaútgáfan, 2008c.

Hagemann, Gro. Skolefolk: Lærernes historie i Norge. Oslo: Gyldendal, 1992.

Hagemann, Gro. De modern gennombrudd 1870-1905. Aschehougs Norgeshistorie IX, edited by Knut Helle. Oslo: H. Aschenhoug, 1997. 
Icelandic schoolteachers 1909-1961. Database (School of Education, University of Iceland c/o Loftur Guttormsson and Ólöf Garðarsdóttir).

Jensen, Eivind Bråstad. ”Skolverket og de tre stammer møte.” Eureka 7 (2005).

Jónsson, Guðmundur and Magnús S. Magnússon, eds. Hagskinna: Icelandic Historical Statistics. Reykjavík: Statistics Iceland, 1997.

Kristjánsson, Ólafur P. ed. Kennaratal á Íslandi I-II. Reykjavík: Oddi, 1958.

Kristjánsson, Ólafur P. and Sigrún Harðardóttir, eds. Kennaratal á Íslandi III-V. Reykjavík: Oddi, 1985-1988.

Minde, Henry. "Assimilation of the Sami - Implementation and Consequences." Acta Borealia 2 (2003).

Nissen, Gunhild. Bønder, skole og demokrati: En undersøgelse i fire provstier af forholdet mellem den offentlige skole og befolkningen på landet i tiden ca. 18801910. Copenhagen: Institut for Dansk Skolehistorie, 1973.

Sjöberg, Mats. Att säkra familjens skördar: Barndom, skola och arbete i agrar miljö: Bolstad pastorat 1860-1930. Linköping: Linköping universitet, 1996.

\section{Endnotes}

${ }^{i}$ With a new Education Act passed in 1946 compulsory education was prolonged by one year (from seven to eight years). At the same time compulsory education was divided into two separate school levels, the primary school level (7-12 years) and lower secondary level (13-14 years). In many cases, the lower secondary schools were part of the so-called gagnfræðaskólar offering a four year study.

ii Strictly speaking, the dataset does not only include compulsory school-teachers, i.e. those who taught a the primary and lower secondary level (13-14 years) but also inviduals teaching at the same time at the upper secondary level (15-16 years). Our dataset does not allow a distinction of this group. It is important to bear in mind that the majority of the seconadary school teachers in question were teaching at both levels. 